\title{
Solar photovoltaic module performance characterisation using single diode modeling
}

\author{
Javed K. Sayyad ${ }^{l, *}$ and Paresh S. Nasikkar ${ }^{l}$ \\ ${ }^{1}$ Symbiosis Institute of Technology, Symbiosis International (Deemed University), Lavale, Pune, 412115 Maharashtra (India).
}

\begin{abstract}
Single or double diode electrical modeling of SPV module gives valuable results which will help to identify the exact behavior of SPV module under the normal operating condition. Accurate modelling of SPV module will also help to calculate internal resistances $\left(R_{s}, R_{s h}\right)$ and parasitic of the SPV module. The main contribution of this work is the stepwise simplification of the current equation of single and double diode electrical model of SPV module. Then the single diode model of SPV module having 36 SPV cells in series is simulated in LTspice simulator. Simulated results are compared with labelled electrical parameters which shows close proximity to the labelled parameter at particular values of series and shunt resistance. This paper also presents the effect of variation in series resistance $\left(R_{s}\right)$ and shunt resistance $\left(R_{s h}\right)$ on the performance of the SPV module under normal operating condition. The dependency of SPV electrical parameters $\left(I_{\max }, V_{\max }, P_{\max }, F F, \eta\right)$ with the variation of series resistance $\left(R_{s}\right)$ and shunt resistance $\left(R_{s h}\right)$ is simulated, and the effects are discussed in details.
\end{abstract}

\section{INTRODUCTION}

In 1839, A French Physicist, E. Becquerel has investigated and observed Photovoltaic (PV) effect which converts incident light energy into electrical energy. Now a days Solar Photovoltaic (SPV) energy is most evolving and fast growing technique to fulfills the need of electricity of mankind [1-3]. The SPV cell is the basic unit of SPV module. SPV Cells are connected in series to get an output of the desired value of voltage. Similarly, the dimension of SPV cells will decide the current rating pf SPV module.

The parameters like module temperature $\left(T_{m}\right)$, incident solar irradiation $(G)$, and load impedance states the conversion efficiency $(\eta)$ of photovoltaic module [4-7]. The major disadvantage of commercially available SPV module is its low conversion efficiency $(\eta<20 \%)$ and the non-linearity of the output I-V curve $[8,9]$. In normal operating condition, meteorological data such as solar irradiance $\left(\mathrm{W} / \mathrm{m}^{2}\right)$, ambient temperature $\left({ }^{0} \mathrm{C}\right)$, humidity $(\% R h)$, and wind velocity $(m p h)$, etc. varies unpredictably. This uncertain variation affects current, voltage and hence power output generated by the SPV module $[10,11]$.

Manufacturers provide labelled electrical parameters (specification given on backside of SPV panel) and performance characteristic curves of SPV module for optimized power generation. This parameters are captured indoor under Standard Test Condition (STC) where $G=1000 \mathrm{~W} / \mathrm{m}^{2}, T_{m}=25^{\circ} \mathrm{C}$ and $A M$ (Air Mass) = 1.5 [12]. Commonly, SPV cell is modeled using a single diode model circuit equivalence [13]. To improve precision and accuracy, it can be modeled using a double diode model circuit equivalence [14]. Proper electrical modelling of SPV module will help to predict accurate performance actual operation condition [15].

In section 2, a need for SPV module performance characterisation is described with some definitions of significant parameters. Single and double diode modeling is compared with mathematical derivations of currents in section 3 . In section 4 , the single diode model of ASP-12-75 $W_{p}$ SPV module is simulated in SPICE simulator. In section 5 , the results of the simulation are presented and compared for variation in series and parallel resistance. The conclusion of the work is presented in section 6 .

\section{CHARACTERISATION}

Performance characterisation of SPV module/cell by tracing I-V and P-V curves is helpful while designing new SPV power plant. It also useful for scheduling Operation and Maintenance (O\&M) of the SPV power plant [16]. Fig. 1 shows that during curve SPV cell/module is swept under different load conditions using variable resistor [17]. SPV cell is an active device which generates energy from incident solar light. Fig. 2 shows that, the I-V and P-V curve of an illuminated SPV cell.

$\mathrm{I}-\mathrm{V}$ and $\mathrm{P}-\mathrm{V}$ characteristic curve is used for extracting some important performance parameters like short circuit current $\left(I_{s c}\right)$, open circuit voltage $\left(V_{o c}\right)$, Maximum power $\left(P_{\max }\right)$, voltage at maximum power $\left(V_{\max }\right)$, current

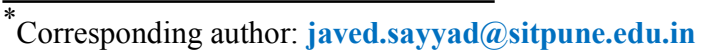


at maximum power $\left(I_{\max }\right)$, conversion efficiency $(\eta)$ and field factor $(F F)$ [18].

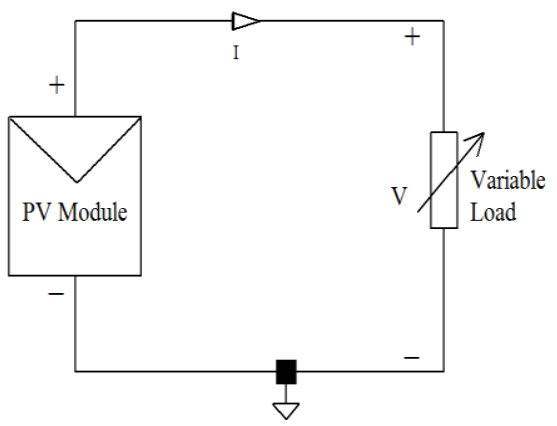

Fig. 1. Characterisation of SPV module

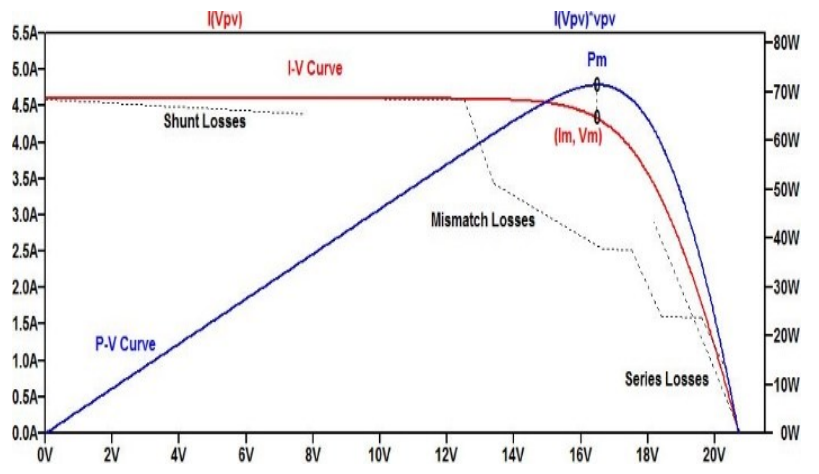

Fig. 2. I-V and P-V Curve

\subsection{Significance of Series Resistance $\left(R_{s}\right)$}

Slope near $V_{\text {oc }}$ is determined by series resistance $\left(R_{S}\right)$ as shown in Fig. 2 and the value of $R_{S}$ is calculated by using Equation 1;

$R_{S}=-\left(\frac{d V}{d I}\right)_{V=V_{o c}}$

Resistance due to SPV cell metallization, SPV cell solder bonds, emitter-base region, cell interconnected bus-bars and junction box terminations implies finite value of series resistance in electrical equivalence circuit modeling. The ideal value of $R s$ is 0 [19]. The value of $I_{s c}$ is reduced due to high value of $R_{s}$, which shows inverse relation between them.

\subsection{Significance of Shunt Resistance $\left(R_{s h}\right)$}

The ideal value of $R_{s h}$ is infinite but finite value of $R_{s h}$ due to manufacturing defects, device degradation and parallel high conductivity paths through or on the solar cell edges results slope near $I_{s c}[19,20]$. This effect is shown in Fig. 2 and the value of $R_{s h}$ is calculated by using Equation 2;

$R_{s h}=-\left(\frac{d V}{d I}\right)_{I=I_{S C}}$

The low value of $R_{s h}$ leading to higher power loss at output [21].

\section{MODELING OF SPV CELL}

SPV cell is modeled as a current source $\left(I_{p v}\right)$ in parallel with a P-N junction diode in a single diode electrical equivalent circuit model [22]. SPV cell behaves like an only diode if there is no incident light present (dark condition $G=0$ ) to generate any current. With an increase in the intensity of incident light, the current generated by the SPV cell increases [23]. Fig. 3 shows the only diode, and the current flowing through it is given by Equation 3;

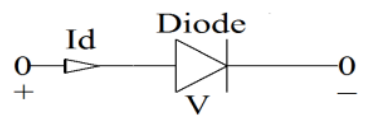

Fig. 3. Single Diode

$I_{d}=I_{o}\left(e^{\frac{q V}{a k T_{m}}}-1\right)$

put;

$v_{t}=\frac{a k T_{m}}{q}$

Equation 5 becomes;

$I_{d}=I_{o}\left(e^{\frac{v}{v_{t}}}-1\right)$

a is ideality factor of diode which is ranging between 1 and 2 (given in datasheet of diode). Considering $\mathrm{a}=1$ at $300 \mathrm{~K}$ temperature, value of $V_{t}$ becomes $25.86 \mathrm{mV}$.

\subsection{Single Diode Modeling (Ideal)}

Fig. 4 shows ideal SPV cell single diode model (Considering $R_{s}=0$ and $R_{s h}=\infty$ );

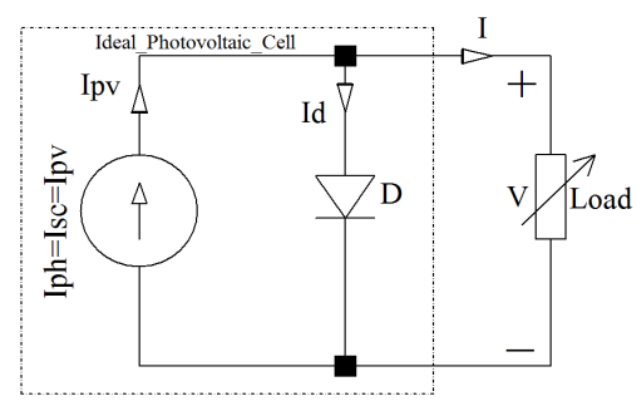

Fig. 4. Simplified Single Diode Modeling of SPV cell (Ideal)

The equation of current flowing through the load is given by Equation 6;

$$
\begin{aligned}
& I=I_{p v}-I_{d} \\
& I=I_{p v}-I_{o}\left(e^{\frac{V}{v_{t}}}-1\right)
\end{aligned}
$$

Fig. 5 shows practical SPV cell single diode model (Considering $R_{s h}=\infty$ ); 


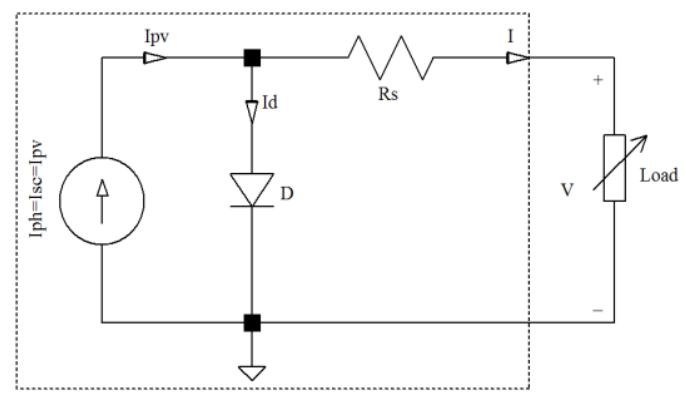

Fig. 5. Single Diode Modeling of SPV cell with $R_{s}$

The equation for practical SPV cell considering $R_{s}$ only is given by Equation 8;

$$
I=I_{p v}-I_{o}\left(e^{\frac{\left(V+I R_{S}\right)}{v_{t}}}-1\right)
$$

Fig. 6 shows practical SPV cell single diode model considering finite values of $R_{s}$ and $R_{s h}$.

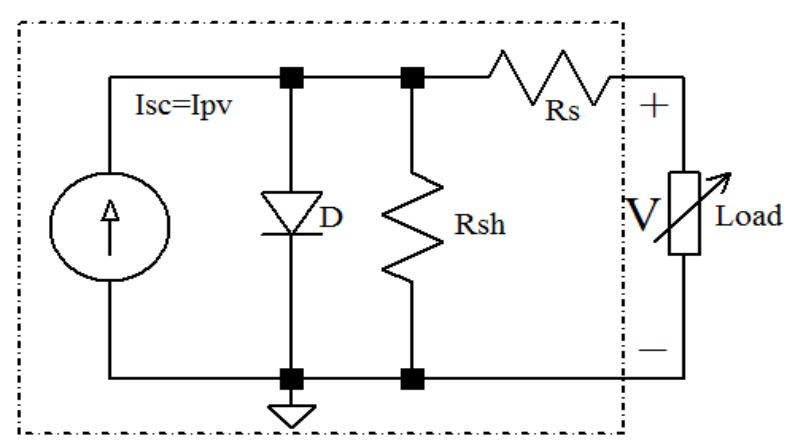

Fig. 6. Single Diode Modeling of SPV cell with $R_{s}$ and $R_{s h}$

Considering $R_{s}$ and $R_{s h}$, the single diode model equation becomes;

$I=I_{p v}-I_{d}-I_{R s h}$

$I=I_{p v}-I_{o}\left(e^{\frac{\left(V+I R_{S}\right)}{v_{t}}}-1\right)-\frac{V+I R_{S}}{R_{s h}}$

Commonly, 36 or 72 cells are connected in series to get desired voltage value at output of SPV module. Different current rating of SPV module depends on physical size of each cell. Cell is bigger in dimension has more current rating. Considering $N_{s}$ as a number of cells are connected in series, equation of practical SPV module becomes;

$I=I_{p v}-I_{o}\left(e^{\frac{\left(V+I R_{S}\right)}{N_{s} v_{t}}}-1\right)-\frac{V+I R_{S}}{R_{S h}}$

This single diode modeling with $R_{s}$ and $R_{s h}$ is also known as five parameter model $\left(I_{o}, \eta, R_{s}, R_{s h}, I_{p v}\right)[13]$

\subsection{Double Diode Modeling}

To increase the precision and accuracy of the equivalence circuit model, many researchers have added several diodes and resistances in series or in parallel with the current source [24]. Fig. 7 shows that, double diode model of the SPV cell considering effect of $R_{s}$ and $R_{s h}$. Double diode model considers the effect of recombination of parallel diode [23]. At low value $G$ and low value of $T_{m}$, this model will give significant and more accurate results. Double diode model has better ability to give mode precise and sharp I-V and P-V characteristics curve under normal as well as partial shading operating condition [25].

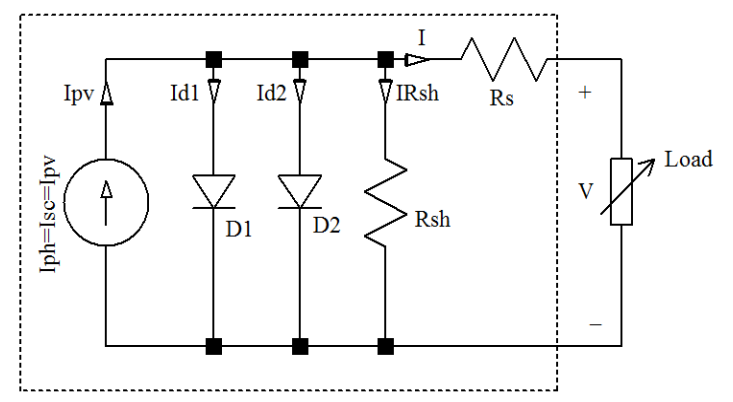

Fig. 7. Double Diode Modeling of SPV cell with $R_{s}$ and $R_{s h}$

The current flowing through load using double diode model is given by Equation 12;

$I=I_{p v}-I_{d 1}-I_{d 2}-I_{R s h}$

$I=I_{p v}-I_{o}\left(e^{\frac{\left(V+I R_{s}\right)}{N_{s 1} v_{t 1}}}-1\right)-I_{o}\left(e^{\frac{\left(V+I R_{s}\right)}{N_{s 2} v_{t 2}}}-1\right)-\frac{V+I R_{S}}{R_{s h}}$

\subsection{Summary of comparison between single and double diode modeling}

Table 1. Comparison of single and double diode model

\begin{tabular}{|l|c|c|}
\hline \multicolumn{1}{|c|}{ Quantities } & $\begin{array}{c}\text { Single } \\
\text { Diode }\end{array}$ & $\begin{array}{c}\text { Double } \\
\text { Diode }\end{array}$ \\
\hline $\begin{array}{l}\text { Computation time for } \\
\text { parameter extraction }\end{array}$ & Shorter & Longer \\
\hline Unknown parameters & Less & More \\
\hline Accuracy and P-V & Good & Better \\
\hline $\begin{array}{l}\text { I-V Nooth } \\
\text { characteristics }\end{array}$ & Sharp \\
\hline $\begin{array}{l}\text { Consider recombination } \\
\text { effect }\end{array}$ & No & Yes \\
\hline
\end{tabular}

\section{SPICE SIMULATION OF SINGLE DIODE MODELING}

Labelled parameter of ASP-12-75 $W_{p}$ SPV module is used as a reference which are calculated under standard test condition, $1000 \mathrm{~W} / \mathrm{m}^{2}$ and $\mathrm{T}=25^{\circ} \mathrm{C}$ given in Table 2 . 
Table 2. Labelled Specification of SPV Module

\begin{tabular}{|c|c|}
\hline \multicolumn{2}{|c|}{$\begin{array}{l}\text { ASP-12-75 } W_{p} \text { SPV Mono-crystalline }\left(1000 \mathrm{~W} / \mathrm{m}^{2} \text {, }\right. \\
\left.25^{\circ} \mathrm{C}\right)\end{array}$} \\
\hline Electrical Parameter & $\begin{array}{l}\text { Specification } \\
\text { at STC }\end{array}$ \\
\hline Maximum Power $\left(P_{\max }\right)$ & $75 W_{p}$ \\
\hline Voltage at Maximum Power $\left(V_{\max }\right)$ & $17.60 \mathrm{~V}$ \\
\hline Current at Maximum Power $\left(I_{\max }\right)$ & $4.26 \mathrm{~A}$ \\
\hline Open Circuit Voltage $\left(V_{o c}\right)$ & $21.5 \mathrm{~V}$ \\
\hline Short Circuit Current $\left(I_{s c}\right)$ & $4.60 \mathrm{~A}$ \\
\hline $\begin{array}{l}\text { Number of series connected SPV } \\
\text { cell }\left(N_{s}\right)\end{array}$ & 36 \\
\hline
\end{tabular}

Single diode model of complete SPV module having 36 SPV cells $\left(N_{s}=36\right)$ in series is simulated in SPICE simulation software assuming all cells are identical and having equal solar radiation. Photon current $\left(I_{p v}=I_{s c}\right)$ flowing through SPV cell is directly proportional to input incident light energy [12]. Leakage current of diode is considered as $1 \mathrm{nA}$. Current controlled current source (CCCS) having current gain 1 is used which gives same current at output of voltage controlled voltage source (VCVS). VCVS is used to multiply single cell voltage with number of cells in series in the SPV module $\left(N_{s} * E_{p v 0}\right)$. Considering uniform operating condition, multiplication of SPV cell output with 36 will shows that there is no possibility under consideration of partial shading condition in simulation. Fig. 8 shows the single diode model of SPV module.

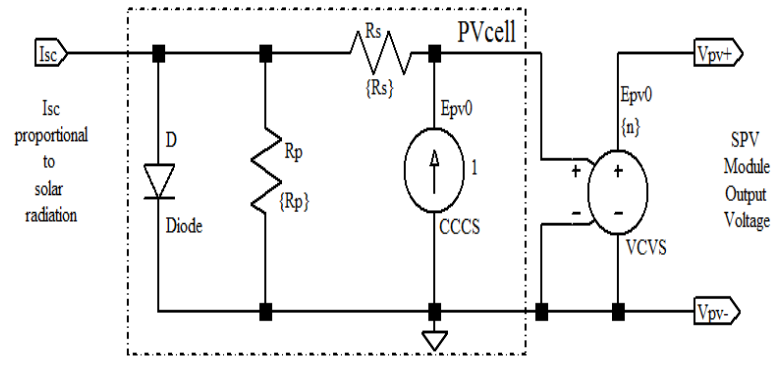

Fig. 8. Simulated single diode model (X1)

Current source of $4.60 A$ represents $I_{s c}$ of SPV module $\left(\mathrm{ASP}-12-75 W_{p}\right)$ which is proportional to solar radiation incident on SPV module. Fig. 9 shows the final equivalence model of SPV panel with $\mathrm{X} 1$ is the solar panel symbol assuming internal resistance of voltmeter $\left(R_{\text {internal }}\right)$ is $0.01 \Omega$.

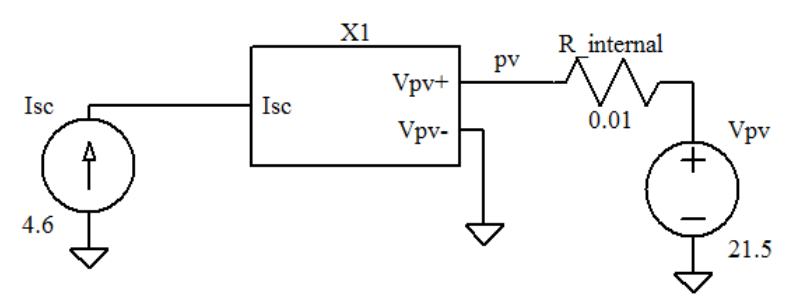

Fig. 9. Complete model in SPICE Simulator

\section{RESULTS AND DISCUSSIONS}

In order to validate single diode modeling and SPICE simulation for above SPV module, the specified values of the ASP-12-75 $W_{p}$ SPV module are compared with simulation results for different combination of $R_{s}$ and $R_{s h}$. In this section, effect of variation of $R_{s}$ and $R_{s h}$ on characteristic curve is observed carefully. The I-V and $\mathrm{P}-\mathrm{V}$ characteristic curves from SPICE simulation of single diode model of SPV module are presented in this section. The effect of $R_{s}$ and $R_{s h}$ variation on SPV module characteristics curve is validated.

\subsection{Effect on $R_{s}$}

In this case, the series resistance $R_{s}$ of single diode model was varied in multiple of 10 from $0.0001 \Omega$ to $1 \Omega$ with all other parameters kept constant $\left(R_{s h}=1 \mathrm{~K} \Omega\right)$. The results (I- $\mathrm{V}$ and $\mathrm{P}-\mathrm{V}$ curves) are presented in Fig. 10 to Fig. 14. From this figures, it may be noted that with increase in series resistance $\left(R_{s}\right)$, the slope near $V_{o c}$ decreases which effectively decreases output power of SPV module and it is tabulated in Table 3.

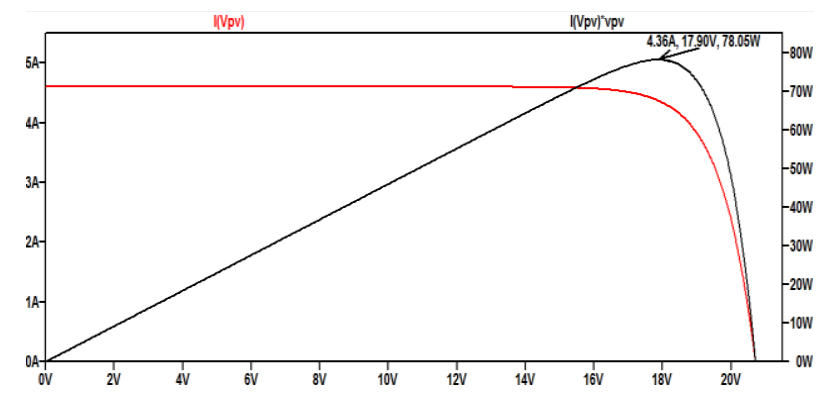

Fig. 10. I-V and P-V Curve with $R_{s}=10^{-4} \Omega$ and $R_{s h}=1 \mathrm{~K} \Omega$

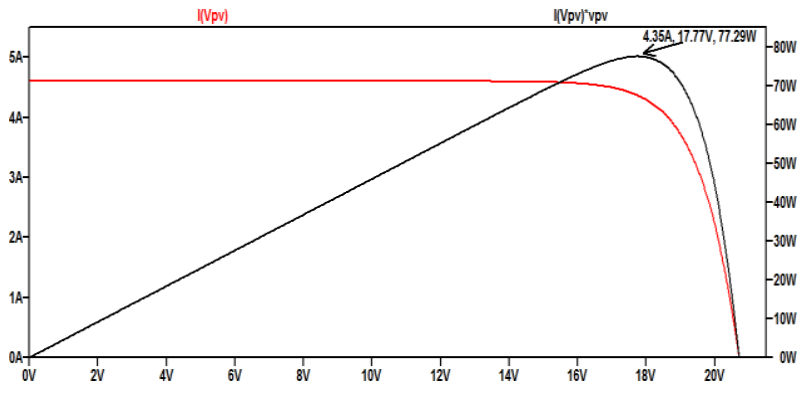

Fig. 11. I-V and P-V Curve with $R_{S}=10^{-3} \Omega$ and $R_{s h}=1 \mathrm{~K} \Omega$

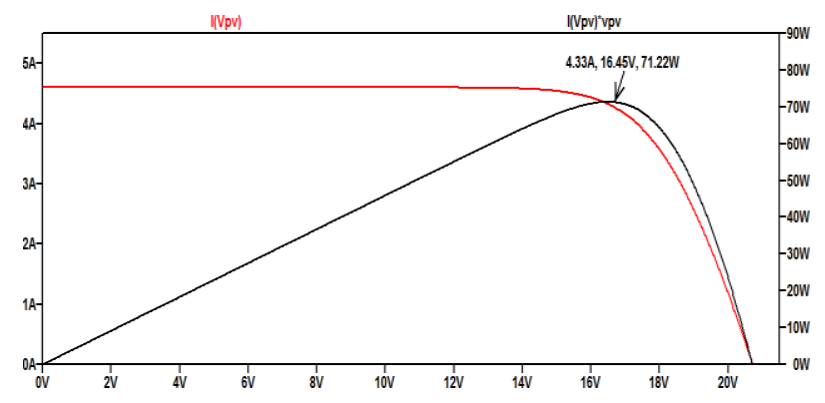

Fig. 12. I-V and P-V Curve with $R_{s}=10^{-2} \Omega$ and $R_{s h}=1 \mathrm{~K} \Omega$ 


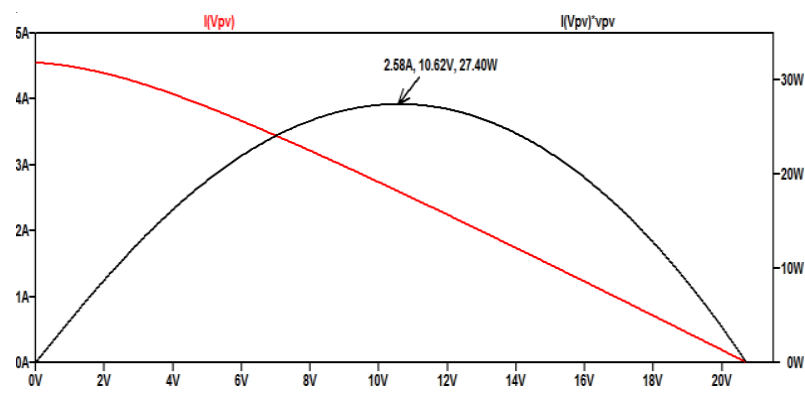

Fig. 13. $\mathrm{I}-\mathrm{V}$ and $\mathrm{P}-\mathrm{V}$ Curve with $R_{S}=10^{-1} \Omega$ and $R_{s h}=1 \mathrm{~K} \Omega$

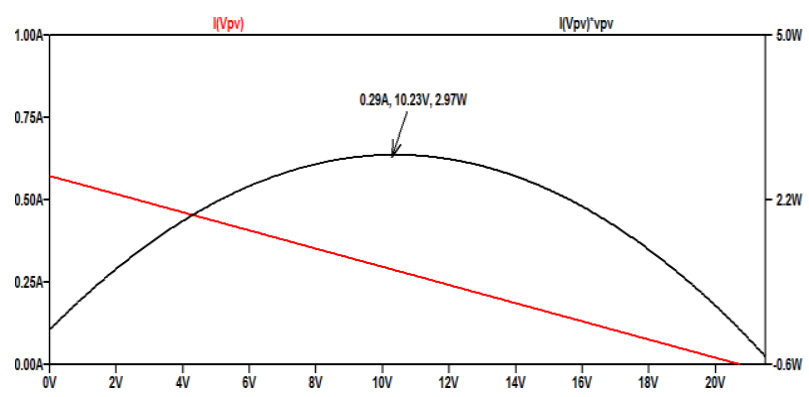

Fig. 14. $\mathrm{I}-\mathrm{V}$ and $\mathrm{P}-\mathrm{V}$ Curve with $R_{s}=1 \Omega$ and $R_{s h}=1 \mathrm{~K} \Omega$

Table 3. Effect of $R_{s}$ Variation

\begin{tabular}{|l|l|l|l|l|l|}
\hline & \multicolumn{5}{|c|}{ Value } \\
\hline $\boldsymbol{R}_{\boldsymbol{S}}(\boldsymbol{\Omega})$ & $10^{-4}$ & $10^{-3}$ & $10^{-2}$ & $10^{-1}$ & 1 \\
\hline $\boldsymbol{R}_{\boldsymbol{s h}}(\boldsymbol{\Omega})$ & \multicolumn{5}{|c|}{$\mathbf{~ K \Omega}$} \\
\hline $\boldsymbol{I}_{\max }(\boldsymbol{A})$ & 4.36 & 4.35 & 4.33 & 2.68 & 0.29 \\
\hline $\boldsymbol{V}_{\max }(\boldsymbol{V})$ & 17.90 & 17.77 & 16.45 & 10.62 & 10.23 \\
\hline $\boldsymbol{P}_{\max }$ & 78.05 & 77.29 & 71.22 & 27.40 & 2.97 \\
$\left(\boldsymbol{W}_{\boldsymbol{p}}\right)$ & & & & & \\
\hline
\end{tabular}

\subsection{Effect on $R_{s h}$}

In this case, the shunt resistance $\left(R_{s h}\right)$ of single diode model was varied in multiple of 100 from $0.1 \Omega$ to $10 M \Omega$ with all other parameters kept constant $\left(R_{S}=0.01 \Omega\right)$. The results (I-V and $\mathrm{P}-\mathrm{V}$ curves) are presented in Fig. 15 to Fig. 19. From this figures, it may be noted that with increase in shunt resistance $\left(R_{s h}\right)$ the slope near $I_{s c}$ changes and output power increases which is tabulated in Table 4.

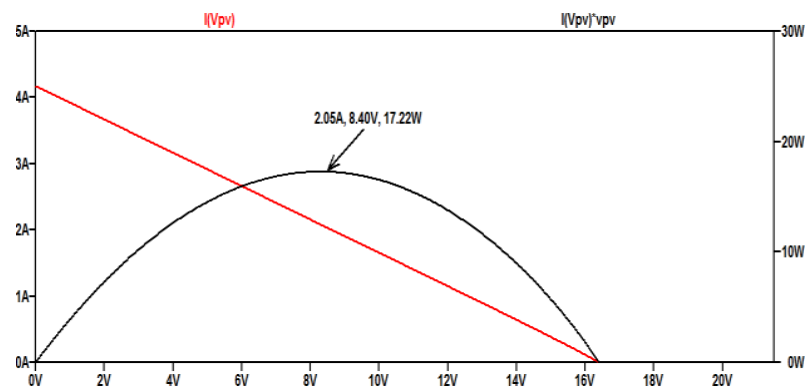

Fig. 15. I-V and P-V Curve with $R_{s h}=0.1 \Omega$ and $R_{s}=0.01 \Omega$

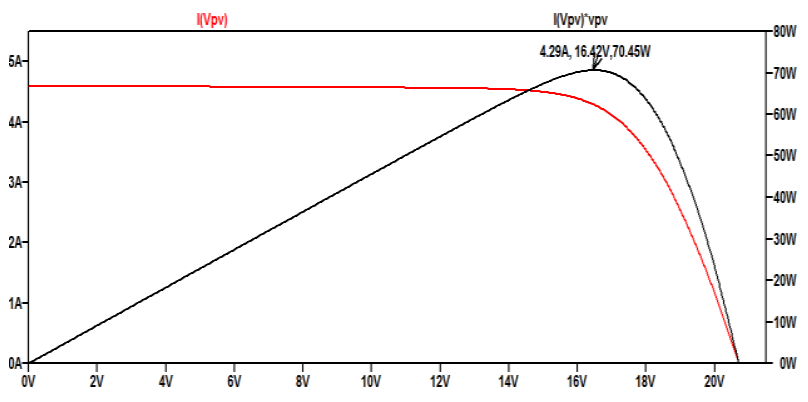

Fig. 16. $\mathrm{I}-\mathrm{V}$ and P-V Curve with $R_{s h}=10 \Omega$ and $R_{s}=0.01 \Omega$

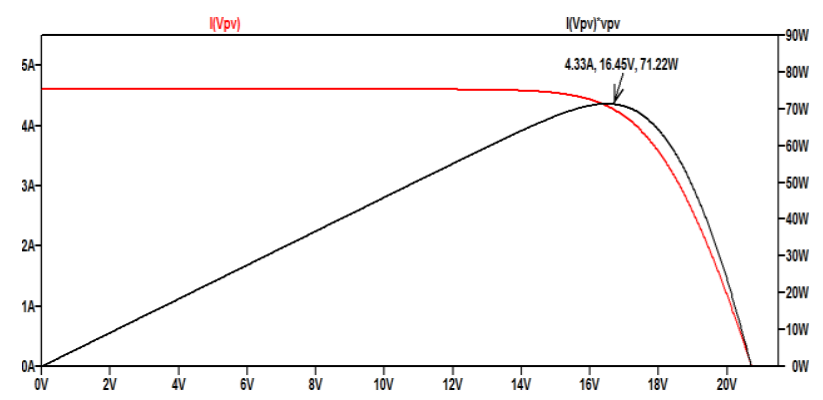

Fig. 17. I-V and P-V Curve with $R_{s h}=1 K \Omega$ and $R_{s}=0.01 \Omega$

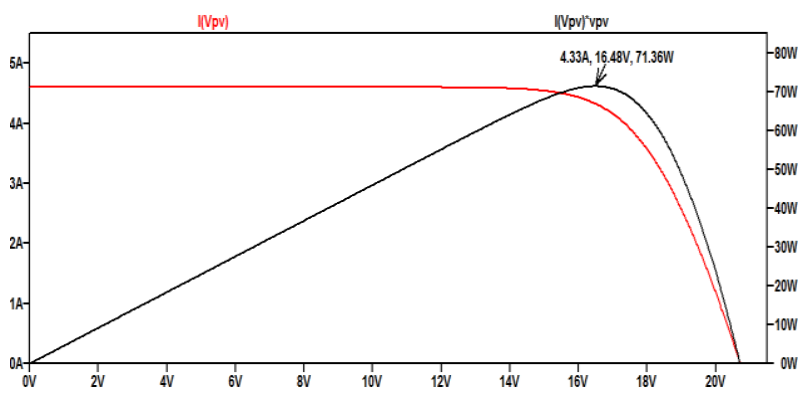

Fig. 18. $\mathrm{I}-\mathrm{V}$ and $\mathrm{P}-\mathrm{V}$ Curve with $R_{s h}=100 K \Omega$ and $R_{s}=0.01 \Omega$

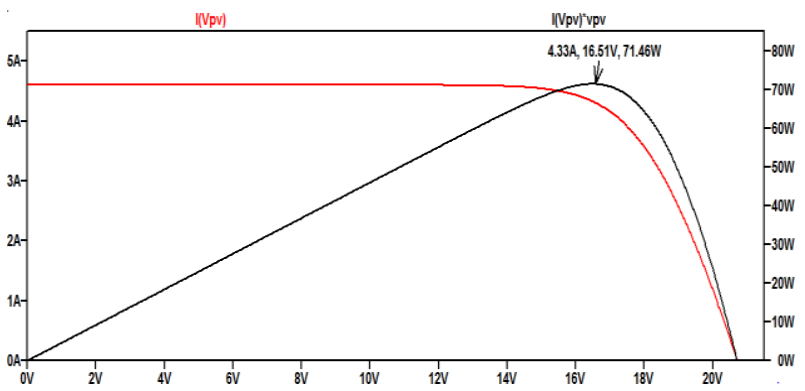

Fig. 19. $\mathrm{I}-\mathrm{V}$ and $\mathrm{P}-\mathrm{V}$ Curve with $R_{s h}=10 M \Omega$ and $R_{s}=0.01 \Omega$

Table 4. Effect of $R_{s h}$ Variation

\begin{tabular}{|l|l|l|l|l|l|}
\hline \multicolumn{5}{|c|}{ Value } \\
\hline $\boldsymbol{R}_{\boldsymbol{s}}(\boldsymbol{\Omega})$ & \multicolumn{5}{|c|}{$\mathbf{0 1}$} \\
\hline $\boldsymbol{R}_{\boldsymbol{s h}}(\boldsymbol{\Omega})$ & 0.1 & 10 & $10^{3}$ & $10^{5}$ & $10^{7}$ \\
\hline $\boldsymbol{I}_{\max }(\boldsymbol{A})$ & 2.05 & 4.29 & 4.33 & 4.33 & 4.33 \\
\hline $\boldsymbol{V}_{\max }(\boldsymbol{V})$ & 8.40 & 16.42 & 16.45 & 16.48 & 16.51 \\
\hline $\boldsymbol{P}_{\max }$ & 17.22 & 70.45 & 71.22 & 71.36 & 71.46 \\
$\left(\boldsymbol{W}_{p}\right)$ & & & & & \\
\hline
\end{tabular}




\section{CONCLUSION}

A detailed comparative study of single and double diode electrical modeling was carried with their advantages and disadvantages. The ideal value of series resistance $\left(R_{s}\right)$ is 0 , but finite value shows the change in the slope of a curve near $V_{o c}$. Similarly, the ideal value of shunt resistance $\left(R_{s h}\right)$ is $\infty$, but finite value shows the change in slope of curve near $I_{s c}$. The results presented in the above section clearly shows that as $R_{s}$ increases the output power decreases. Similarly increases in $R_{s h}$ value, the output power increases. The implemented single diode model of SPV module gives results having close proximity with a labelled specification of ASP-12-75 $W_{\mathrm{p}}$ SPV module with a low value of $R_{s}$ and high value of $R_{s h}$ under normal operating conditions at a constant temperature and constant solar irradiance

\section{References}

1. Kurtz, S., Opportunities and challenges for development of a mature concentrating photovoltaic power industry. 2012: Citeseer.

2. Friedman, D.J., et al., Toward 100 Gigawatts of concentrator photovoltaics by 2030. IEEE Journal of Photovoltaics, 2013. 3(4): p. 1460-1463.

3. Branker, K., M. Pathak, and J.M. Pearce, $A$ review of solar photovoltaic levelized cost of electricity. Renewable and sustainable energy reviews, 2011. 15(9): p. 4470-4482.

4. Ibrahim, H. and N. Anani, Variations of PV module parameters with irradiance and temperature. Energy Procedia, 2017. 134: p. 276-285.

5. Siddiqui, R. and U. Bajpai, Deviation in the performance of solar module under climatic parameter as ambient temperature and wind velocity in composite climate. International Journal of Renewable Energy Research, 2012. 2(3): p. 486-490.

6. Xiao, C., et al., Impact of solar irradiance intensity and temperature on the performance of compensated crystalline silicon solar cells. Solar Energy Materials and Solar Cells, 2014. 128: p. 427-434.

7. Hishikawa, Y., et al., Precise Outdoor PV Module Performance Characterization Under Unstable Irradiance. IEEE Journal of Photovoltaics, 2016. (5): p. 1221-1227.

8. Kandemir, E., N.S. Cetin, and S. Borekci, $A$ comprehensive overview of maximum power extraction methods for PV systems. Renewable and Sustainable Energy Reviews, 2017. 78: p. 93-112.

9. Vorster, F. and E. Van Dyk, Current-voltage characteristics of high-concentration, photovoltaic arrays. Progress in Photovoltaics: Research and Applications, 2005. 13(1): p. 55-66.

10. Engeland, K., et al., Space-time variability of climate variables and intermittent renewable electricity production - A review. Renewable and Sustainable Energy Reviews, 2017. 79: p. 600-617.

11. Kahoul, N., et al., Evaluating the reliability of crystalline silicon photovoltaic modules in harsh environment. Renewable Energy, 2017. 109: p. 66-72.

12. Kawagoe, K., Y. Hishikawa, and N. Yamada, Outdoor Direct STC Performance Measurement of PV Modules Based on a Sun-Shading Technique. IEEE Journal of Photovoltaics, 2017. 7(6): p. 1725-1730.

13. Lineykin, S., M. Averbukh, and A. Kuperman. Five-parameter model of photovoltaic cell based on STC data and dimensionless. in 2012 IEEE 27th Convention of Electrical and Electronics Engineers in Israel. 2012.

14. Bellia, H., R. Youcef, and M. Fatima, $A$ detailed modeling of photovoltaic module using MATLAB. NRIAG Journal of Astronomy and Geophysics, 2014. 3(1): p. 53-61.

15. Bana, S. and R.P. Saini, A mathematical modeling framework to evaluate the performance of single diode and double diode based SPV systems. Energy Reports, 2016. 2: p. 171-187.

16. Amiry, H., et al., Design and implementation of a photovoltaic I-V curve tracer: Solar modules characterization under real operating conditions. Energy Conversion and Management, 2018. 169: p. 206-216.

17. Warner, T.H. and C.H. Cox, I-V CURVE TRACER EMPLOYNG PARAMETRIC SAMPLNG, USA, Editor. 1984: USA.

18. Macabebe, E.Q.B., C.J. Sheppard, and E.E. van Dyk, Parameter extraction from $I-V$ 
characteristics of $P V$ devices. Solar Energy, 2011. 85(1): p. 12-18.

19. Meyer, E.L. and E.E.v. Dyk, Assessing the reliability and degradation of photovoltaic module performance parameters. IEEE Transactions on Reliability, 2004. 53(1): p. 83-92.

20. Rummel, S. and T. J. McMahon, Effect of cell shunt resistance on $P V$ module performance at reduced light levels. Vol. 353. 1996: American Institute of Physics. 581-586.

21. Tamrakar, V., S.C. Gupta, and Y. Sawle. Study of characteristics of single and double diode electrical equivalent circuit models of solar PV module. in International Conference on Energy Systems and Applications 2015. 2015. Dr. D. Y. Patil Institute of Engineering and Technology, Pune, India.

22. Durgadevi, A., S. Arulselvi, and S.P. Natarajan. Photovoltaic modeling and its characteristics. in 2011 International Conference on Emerging Trends in Electrical and Computer Technology. 2011.

23. Masmoudi, F., F.B. Salem, and N. Derbel. Single and double diode models for conventional mono-crystalline solar cell with extraction of internal parameters. in 2016 13th International Multi-Conference on Systems, Signals \& Devices (SSD). 2016.

24. Ishaque, K., Z. Salam, and H. Taheri, Simple, fast and accurate two-diode model for photovoltaic modules. Solar Energy Materials and Solar Cells, 2011. 95(2): p. 586-594.

25. Yin, O.W. and B.C. Babu, Simple and easy approach for mathematical analysis of photovoltaic $(P V)$ module under normal and partial shading conditions. Optik, 2018. 169: p. 48-61. 